Journal of Animal and Veterinary Advances 11 (8): 1237-1241, 2012

ISSN: $1680-5593$

(C) Medwell Journals, 2012

\title{
Porcine $R P L 28$ Gene, Differentially Expressed in the Backfat Tissue Between Meishan, Large White Pigs and Their F1 Hybrids
}

\author{
Z.Q. Ren, Y.Z. Xiong, W.J. Wu, C.Y. Deng and S.W. Jiang \\ Key Laboratory of Swine Genetics and Breeding of Ministry of Agriculture, \\ Key Laboratory of Agriculture Animal Genetics, \\ Breeding and Reproduction of Ministry of Education, \\ Department of Animal Science and Technology, College of Animal Science, \\ Huazhong Agricultural University, 430070 Wuhan, P.R. China
}

\begin{abstract}
The mRNA differential display technique was performed to investigate the differences in gene expression in the backfat tissues between Meishan, Large White pigs and their F1 hybrids. One novel gene that was differentially expressed was identified through both semi-quantitative Reverse Transcriptase Polymerase Chain Reaction (RT-PCR) and Quantitative reverse transcriptase Polymerase Chain Reaction (Q-PCR) and it was highly expressed in F1 hybirds, Meishan x Large White and Large White x Meishan compared to their parents. The full-length cDNA was then cloned using the Rapid Amplification of cDNA Ends (RACE) Method. The nucleotide sequence of the gene is not homologous to any of the known porcine genes. The sequence prediction analysis revealed that the open reading frame of this gene encods a protein of 137 amino acids has high homology with the RPL 28 of seven species-cattle (97\%), human (97\%), mouse (95\%) and rat (97\%) so that it can be defined as the porcine RPL28 gene. Tissue expression profile analysis indicated that the swine RPL28 gene is differentially expressed in detected tissues. The experiment suggested that the swine $R P L 28$ gene might play role in the formation of heterosis.
\end{abstract}

Key words: RPL28, differential expression, pig, heterosis, backfat, China

\section{INTRODUCTION}

In agriculture, the use of heterosis in part animals and crop plants has achieved great success and is considered essential to meet the world's food needs (Duvick, 1999; Phillips, 1999; Nassimi et al., 2006). The hypothesis of Dominance, Superdominace and Epistasis has also been brought forward to explain the phenomenon of heterosis for a century.

However, the molecular mechanism of heterosis or hybrid vigor remains to be revealed. The development in QTL (Quantitative Trait Loci) mapping method has made a large advancement on studying the relationships between heterosis and the modes of QTL interactions on plants (Lu et al., 2003; Syed and Chen, 2004; Farooq and Azam, 2002; Mirshamsi et al., 2008). The heterosis is in fact the external exhibition of gene expression and regulation in the heterozygote (Zhu, 2000). So, the study on heterosis in expressional level becomes more meaningful. A lot of studies on heterosis in this level have been done both in plants (Romagnoli et al., 1990;
Tsaftaris, 1995; Xiong et al., 1998) and in animals (Liu et al., 2004; Wang et al., 2004). They have found that certain genes are actually differentially expressed between hybrids and parents and may be related to the formation of heterosis (Wu et al., 2001; Xie et al., 2003).

The mRNA differential display technique is a worldwide method to either identify gene differential expression or to discover novel genes that are involved in important biological pathways (Liang et al., 1993; Liang and Pardee, 1992). The principle of differential display is the systematic amplification of the $3^{\prime}$ termini of mRNAs by using anchored oligo-dT primers in combination with $5^{\prime}$ arbitrary primers. The isolation of the PCR products by gel electrophoresis and their direct comparison allows the identification of differentially expressed genes. Here we report the identification of a differentially expressed gene RPL28 encoding ribosomal protein L28 in the F1 hybirds, Meishan x Large White (MS x LW) and Large White $x$ Meishan (LW x MS) and their parents, Meishan (M) and Large White pigs (LW).

Corresponding Author: Z.Q. Ren, Key Laboratory of Swine Genetics and Breeding of Ministry of Agriculture,

Key Laboratory of Agriculture Animal Genetics, Breeding and Reproduction of Ministry of Education, Department of Animal Science and Technology, College of Animal Science, Huazhong Agricultural University, 430070 Wuhan, P.R. China 


\section{MATERIALS AND METHODS}

Animals: Purebreds, LW and MS and their F1 hybrids LW x MS and MS x LW were from the Pig Jingpin Plant of Huazhong Agricultural University and were bred under the same conditions.

Sample collection and total RNA extraction: Samples of backfats were collected from pigs at slaughter and immediately stored in liquid nitrogen. Total RNA was extracted using TRIzol Reagent (Invotrigen, USA). After that, total RNA was treated with RNase-free DNase I (Promega, USA) to destroy potential contaminating genomic DNA. Total RNA integrity was monitored by denaturing $1 \%$ agarose gel electrophoresis.

Differential display: About $2 \mu \mathrm{g}$ of total RNA pool derived from 6 pigs was obtained as template for reverse transcription. About $0.5 \mu \mathrm{g}$ of the oligo (dT) 15 primer (Promega, USA) per mg of the mRNA sample was added to a total volume of $15 \mu \mathrm{L}$ with DEPC treated $\mathrm{ddH}_{2} \mathrm{O}$. The tube was spun briefly and heated to $70^{\circ} \mathrm{C}$ for $5 \mathrm{~min}$ to denature the template and then cooled immediately on ice/water. The subsequent steps of RT were carried out according to the user manual of $\mathrm{M}-\mathrm{MLV}$ reverse transcriptase (Promega, USA).

The DD-PCR reaction system was $25 \mu \mathrm{L}$ in total containing: $1.0 \mu \mathrm{L}$ cDNA (about $1 \mu \mathrm{g}$ ), $0.5 \mu \mathrm{L} 10 \mathrm{mM}$ mixed dNTPs, $2.5 \mu \mathrm{L} 10 \times$ Taq DNA polymerase buffer, $1.5 \mu \mathrm{L} 25 \mathrm{mM} \mathrm{MgCl}_{2}, 2.0 \mu \mathrm{L}, 10 \mu \mathrm{M}$ anchor and arbitrary primers each, 2.0 units of Taq DNA polymerase $(1 \mathrm{U} / 1 \mu \mathrm{L})$ and $13.5 \mu \mathrm{L}$ sterile water. The PCR was done as follows: $94^{\circ} \mathrm{C}$ for $5 \mathrm{~min}, 40^{\circ} \mathrm{C}$ for $5 \mathrm{~min}, 72^{\circ} \mathrm{C}$ for $5 \mathrm{~min}, 3$ cycles of $94^{\circ} \mathrm{C}$ for $2 \mathrm{~min}, 40^{\circ} \mathrm{C}$ for $2 \mathrm{~min}, 72^{\circ} \mathrm{C}$ for $5 \mathrm{~min}$ followed by 30 cycles of $94^{\circ} \mathrm{C}$ for $1 \mathrm{~min}, 60^{\circ} \mathrm{C}$ for $1 \mathrm{~min}, 72^{\circ} \mathrm{C}$ for $2 \mathrm{~min}$ and then $72^{\circ} \mathrm{C}$ extension for $10 \mathrm{~min}$. After that the PCR products were isolated on $8 \%$ non-denaturing polyacrylamide gel (39:1) following the method described by Liu et al. (2004) and then were visualized by silver staining.

Re-amplification, cloning and sequence analysis: The bands of interest were excised from the gel placed in $40 \mu \mathrm{L} \mathrm{ddH}_{2} \mathrm{O}$, mashed with a tip and then boiled for 10 min. After that, $4 \mu \mathrm{L}$ upper liquid was used for re-amplification, the bands were re-amplificated as follows: $0.5 \mu \mathrm{L} 10 \mathrm{mM}$ mixed dNTPs, $2.5 \mu \mathrm{L} 10 \times$ Taq DNA polymerase buffer, $1.5 \mu \mathrm{L} 25 \mathrm{mM} \mathrm{MgCl}_{2}, 0.5 \mu \mathrm{L} 10 \mu \mathrm{M}$ anchor and arbitrary primers each, 1.0 units of Taq DNA polymerase $(1 \mathrm{U} / 1 \mu \mathrm{L})$ and $14.5 \mu \mathrm{L}$ sterile water. The PCR annealing temperature was $60^{\circ} \mathrm{C}$. The bands of true positive were only cloned using pMD-18T cloning kit (TaKaRa, Japan) and sequenced by Huanuo Company (Shanghai, China). After that the obtained sequences were compared with those available in GenBank using BLAST.

Semi-quantitative RT-PCR: On the basis of the sequences, the forward and reverse specific primers were synthesized to identify these ESTs. Semi-quantitative RTPCR were performed using about 100 ng of cDNA which was same as that of DDRT-PCR, 5 pmoles each specific primers, $200 \mu \mathrm{M}$ of each dNTP, 1 unit of Taq polymerase and $1 \times$ Taq polymerase buffer in a $25 \mu \mathrm{L}$ volume. The PCR program initially started with a $94^{\circ} \mathrm{C}$ denaturation for $4 \mathrm{~min}$ followed by $20-36$ cycles of $94^{\circ} \mathrm{C}$ for $1 \mathrm{~min}, \mathrm{ta}^{\circ} \mathrm{C}$ (ta: annealing temperature) for $1 \mathrm{~min}, 72^{\circ} \mathrm{C}$ for $1 \mathrm{~min}$.

Exponential amplification range for each gene was tested on the adjusted cDNA. 1.25, 2.5 and 5 pmoles of GAPDH primers were added, respectively when 20 cycles were remaining in the specified gene's exponential amplification range. The PCR samples were electrophoresed on $2 \%$ agarose/EtBr gels. Densitometry values were measured using the BandScan Software (www.Glyko.com). RT-PCR values are presented as a ratio of the specified gene's signal in the selected exponential amplification cycle divided by the GAPDH signal. Each sample was repeated eight times in duplicate PCR. The standard deviation for each error bar was calculated according to the eight densitometry values.

SYBR green real-time RT-PCR analysis of RPL28 expression: Real-time relative quantitative RT-PCR was performed denaturing at $95^{\circ} \mathrm{C}$ for $2 \mathrm{~min}$, amplifying for 45 cycles at $95^{\circ} \mathrm{C}$ for $30 \mathrm{sec}$, annealing and extension at $58^{\circ} \mathrm{C}$ for $30 \mathrm{sec}$ and $72^{\circ} \mathrm{C}$ for $18 \mathrm{sec}$, respectively using an MJ option 2 detection system (MJ Research, USA). GAPDH (glyceraldeyhyde-3-phosphate dehydrogenase) primers are: 5'-CGTCCCTGAGACACGATGGT-3' and 5'GCCTGGACTGTG-C CGTGGAAT-3' and RPL28 primers are 5'-CCGCAACTCCTTCCGCTAC-3' and 5'TTGATGGTGGTCCGCACGT-3'.

For spatial expression analysis, total RNAs were also isolated from various tissues including backfat tissue, longissimus dorsi, heart, liver, spleen, lung, kidney, stomach, uterus, ovary and small intestine of Meishan pigs. Each sample was repeated four times and the comparative $\mathrm{C}_{\mathrm{t}}\left({ }^{\Delta \Delta} \mathrm{C}_{\mathrm{t}}\right)$ value method (Livak and Schmittgen, 2001) was used to compute relative quantification. Expression levels were considered not detectable when the $C_{t}$ value of the targeted gene exceeded 35 in the sample tissue. 


\section{RESULTS AND DISCUSSION}

Identification of EST39, an up-regulated gene, in F1 hybrids: One band, designated as EST39 and visualized only in the F1 Large White x Meishan and Meishan x Large White hybrids was isolated from the differential display gel and re-amplified. Semi-quantitative RT-PCR analysis showed that the expression level of EST39 in backfat was higher in the F1 hybrids than in their parents (Fig. 1).

Cloning and analysis of porcine RPL28 gene: The differentially expressed ESTS36 shares $91 \%$ sequence identity with the human RPL28 gene. ESTS36 composes of classic polyadenylation signal, AATAA and poly (A). Researchers obtained a 513 bp full-length porcine RPL28 cDNA by 5 ' RACE-PCR (Fig. 2). Porcine RPL28 gene contains an open reading frame of 137 nucleotides. Researchers inferred that the ATG codon at nucleotide (nt) residue $43-45$ is the true start site of translation because it begins the longest reading frame and is preceded by one in-frame stop codon in the $5^{\prime}$ Untranslated Region (UTR).
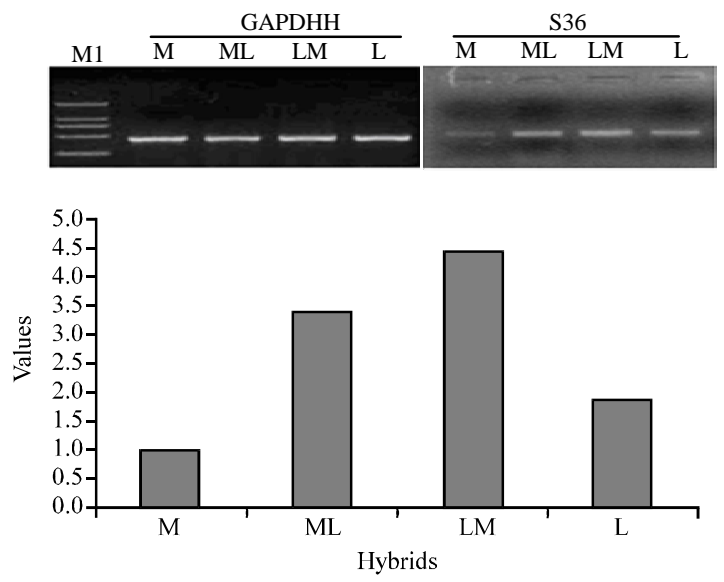

Fig. 1: Identification of ESTS36 as up-regulated gene in backfat of F1 hybrids compared with their parents

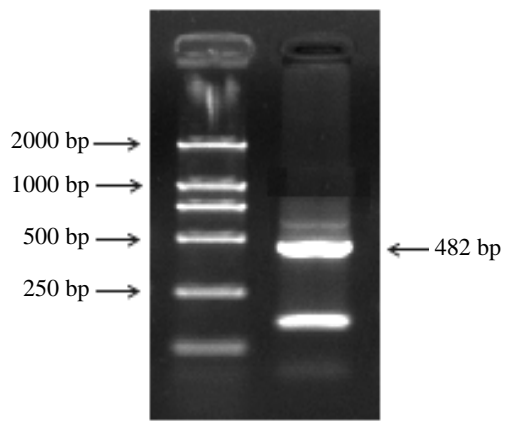

Fig. 2: RACE-PCR amplification of $5^{\prime}$ end of porcine RPL28
Analysis of the RPL28 deduced protein sequence: The porcine transcripts coded for a 383 amino acid peptide with theoretical pI/MW of $11.97 / 15.7 \mathrm{kDa}$ (Fig. 3). The protein of RPL28 gene localized to the cell nucleus by online PSORT Version II U prediction. RPL28 which has not signal peptide sequence is a kind of non-secreted protein by Signal P 3.0 Server analysis.

The phylogenetic tree, constructed using the porcine RPL28 amino acids and other protein sequences of vertebrate isocitrate dehydrogenases available in the GenBank database (Fig. 4) showed two features: the evolutional relationship between porcine RPL28 and cattle, dog and human's is closer than others; the origin of Xenopus laevis RPL28 is earliest followed by zebra fish and mammalian which is consistent with the evolutional process from amphibian to mammalian.

Expression profile of porcine RPL28: Real-time analysis was performed to further reveal the differential expression

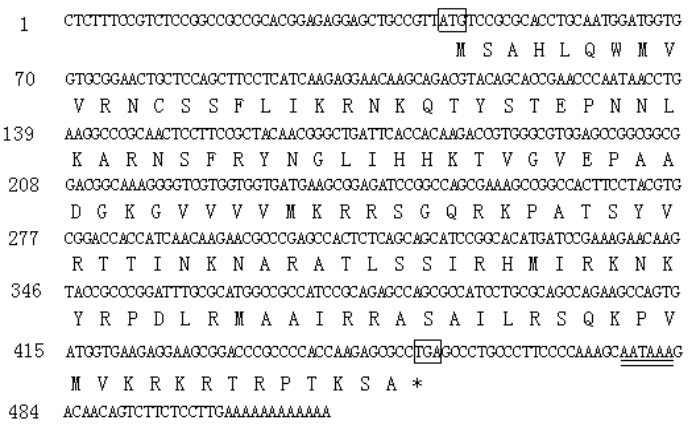

Fig. 3: Full-length cDNA and predicted protein sequence of porcine RPL 28 gene. Initiator codon (ATG) and the stop codon TGA were shown in blank box and asterisk, respectively. The canonical AATAAA polyadenylation signal was double-underlined

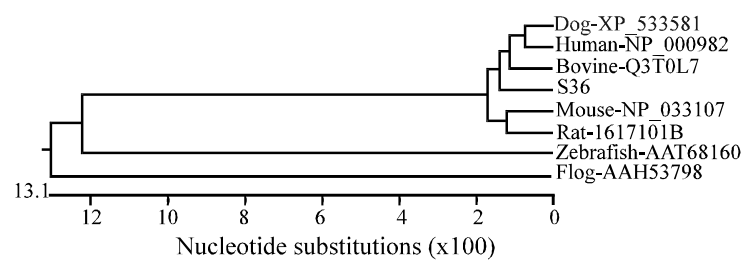

Fig. 4: Phylogenetic relationship of RPL28, the sequences used here are derived from GenBank Database expect for S36 and their accession numbers are followed by the name of species. The horizontal branch lengths are proportional to the estimated divergence of the sequence from the branch point. The vertical branch lengths are arbitrary 


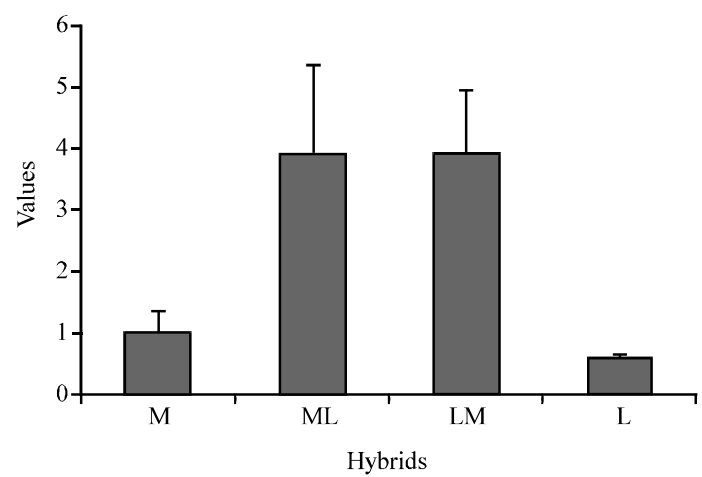

Fig. 5: The expression patterns of RLP28 gene revealed by real-time PCR, the values were normalized to housekeeping GAPDH expression. The value of Meishan pigs were set to 1

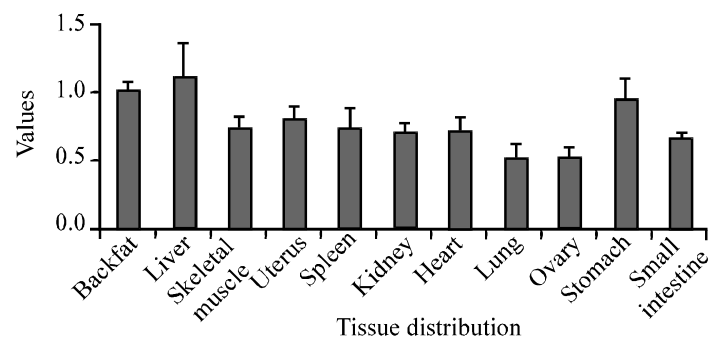

Fig. 6: The tissue distribution of $R L P 28$ gene, the value of backfat sample was set to 1

of RPL28 between F1 hybrids and their parents. GAPDH was used to normalize the expression level of RPL28. The relative quantitative results showed that RPL 28 mRNA in backfat was up-regulated in F1 hybrids as compared with their parents (Fig. 5). Researchers also determined the spatial expression of ACL in various porcine tissues (Fig. 6). The highest level of porcine ACL mRNA expression was observed in the liver followed by the backfat, stomach, uterus, skeletal muscle, spleen cardiac muscle, kidney, small intestine, ovary and lung.

As one of organelles, ribosome plays important role in the synthesis of protein. It was composed of 4 ribosomal RNA (rRNA) and 80 Ribosomal Proteins (RP). Ribosomes are divided into two subunits. The smaller subunit binds to the mRNA while the larger subunit binds to the tRNA and the amino acids. When a ribosome finishes reading an mRNA, these two subunits split apart. The functional research on RP has become one of hotspots due to the revelation of the role of RP on human disease. Some research found that RP not only participated the synthesis of protein but also functioned as endonuclease. For example, RPS3 play role as endonuclease both in mammal and drosophila. Human RPL22 can format RNP complex in combination with EB virus. A little is known about RPL28 gene except for isolation from human and mouse. The full-length of mouse RPL28 cDNA is 555 bp encoding 137 amino acids.

\section{CONCLUSION}

In the present study, the $R P L$ gene expression was up-regulated at backfat of $\mathrm{F} 1$ hybrids and their parents indicating ribosomal protein may be involved in the formation of porcine heterosis.

\section{ACKNOWLEDGEMENTS}

This study was funded by International Foundation for Science (B/4534-1), National Natural Science Foundation of China (31000996), Specialized Research Fund for the Doctoral Program of Higher Education (200805041012) and the Fundamental Research Funds for the Central Universities (2009QC006).

\section{REFERENCES}

Duvick, D.N., 1999. Heterosis: Feeding People and Protecting Natural Resources. In: The Genetics and Exploitation of Heterosis in Crops, Coors, J.G. and S. Pandey (Eds.). American Society of Agronomy Inc., Madison, Wl., USA., pp: 19-29.

Farooq, S. and F. Azam, 2002. Molecular markers in plant breeding-11l: Practical applications and difficulties encountered. Pak. J. Biol. Sci., 5: 1148-1154.

Liang, P. and A.B. Pardee, 1992. Differential display of eukaryotic messenger RNA by means of the polymerase chain reaction. Science, 257: 967-971.

Liang, P., L. Averboukh and A.B. Pardee, 1993. Distribution and cloning of eukaryotic mRNAs by means of differential display: Refinements and optimization. Nucl. Acids Res., 21: 3269-3275.

Liu, G.Y., Y.Z. Xiong, C.Y. Deng, B. Zuo and J.H. Zhang, 2004. Comparison of gene expression patterns in Longissimus dorsi of pigs between the high-parent heterosis cross combination Landrace $\times$ Large White and the mid-parent heterosis cross combination Large White $\times$ Meishan. Asian-Aust. J. Anim. Sci., 17: 1192-1196.

Livak, K.J. and T.D. Schmittgen, 2001. Analysis of relative gene expression data using real-time quantitative PCR and the $2^{-\triangle \Delta C}$ T method. Methods, 25: 402-408.

Lu, H., J. Romero-Severson and R. Bernardo, 2003. Genetic basis of heterosis explored by simple sequence repeat markers in a random-mated maize population. Theor. Appl. Genet., 107: 494-502. 
Mirshamsi, A., M. Farsi, F. Shahriari and H. Nemati, 2008. Use of random amplified polymorphic DNA markers to estimate heterosis and combining ability in tomato hybrids. Pak. J. Biol. Sci., 11: 499-507.

Nassimi, A.W., Raziuddin and N. Ali, 2006. Heterotic studies for yield associated traits in Brassica napus L. using $8 \times 8$ diallel crosses. Pak. J. Biol. Sci., 9: $2132-2136$.

Phillips, R.L., 1999. Research Need in Heterosis. In: The Genetics and Exploitation of Heterosis in Crops, Coors, J.G. and S. Pandey (Eds.)., ASACSSA-SSSA Societies, Madison, WI, pp: 501-508.

Romagnoli, S., M. Maddaloni, C. Livini and M. Motto, 1990. Relationship between gene expression and hybrid vigor in primary root tips of young maize (Zea mays L.) plantlets. Theory Appl. Genet., 80: 767-775.

Syed, N.H. and Z.J. Chen, 2004. Molecular marker genotypes, heterozygosity and genetic interactions explain heterosis in Arabidopsis thaliana. Heredity, 94: 295-304.

Tsaftaris, A.S., 1995. Molecular aspects of heterosis in plants. Physiol. Plant., 94: 362-370.
Wang, D., Y. Zhang, D.X. Sun, Y. Yu, G.Y. Xu and J.Y. Li, 2004. Gene differential expression of liver tissues in crossbred versus purebred chicken and their relationship with heterosis of meat trait. Acta Genet. Sin., 31: 257-264.

Wu, L.M., Z.F. Ni and Q.X. Sun, 2001. Relationship between differential expression patterns of multugene families and heterosis in a wheat diallel cross. Acta Genet. Sin., 28: 256-266.

Xie, X.D., Z.F. Ni, F.R. Meng, L.M. Wu, Z.K. Wang and Q.X. Sun, 2003. Relationship between difference of gene expression in early developing seeds of hybrid versus parents and heterosis in wheat. Acta Genet. Sin., 30: 260-266.

Xiong, L.Z., G.P. Yang and Q.F. Zhang, 1998. Relationship of differential gene expression in leaves with heterosis and heterozygosity in a rice diallel cross. Mol. Breed., 4: 129-136.

Zhu, Y.G., 2000. Biology of Cytoplasmic Male Sterility in Rice. Wuhan University Press, Wuhan, China, Pages: 485. 